\title{
Analysis of HIV Incidence in Female Sex Workers (WPS) in Wanasari Village Cibitung District, Bekasi Regency 2019
}

\author{
$1^{\text {st }}$ A J Rifiana \\ Department Midwifery \\ Faculty of Health Sciences Universitas \\ Nasional \\ Jl. Sawo Manila, RT.14/RW.3, Ps. \\ Minggu, Kec. Ps. Minggu, Kota Jakarta \\ Selatan, Daerah Khusus Ibukota Jakarta \\ 12520, Indonesia \\ andi.rifiana@civitas.unas.ac.id
}

\author{
$2^{\text {nd }} \mathrm{R}$ G S Darma \\ Department Midwifery \\ Faculty of Health Sciences Universitas \\ Nasional \\ Jl. Sawo Manila, RT.14/RW.3, Ps. \\ Minggu, Kec. Ps. Minggu, Kota Jakarta \\ Selatan, Daerah Khusus Ibukota Jakarta \\ 12520, Indonesia
}

\author{
$3^{\text {rd }}$ R Kundaryanti \\ Department Midwifery \\ Faculty of Health Sciences Universitas \\ Nasional \\ Jl. Sawo Manila, RT.14/RW.3, Ps. \\ Minggu, Kec. Ps. Minggu, Kota Jakarta \\ Selatan, Daerah Khusus Ibukota Jakarta \\ 12520, Indonesia
}

\begin{abstract}
The spread of HIV continues to increase and causes more than 12,800 new infections every day. AIDS is now the leading cause of death in Africa and in a quarter of the world. The number of HIV / AIDS cases reported from 2005 to December 2017 was 200,623. Bekasi Regency with a case ratio of 1,363 people with HIV / AIDS. At present the number has increased by $13.7 \%$ to 1,551 cases. The results of this study indicate that factors related to the incidence of HIV / AIDS in female sex workers (WPS) in Wanasari Village, Cibitung District, Bekasi Regency in 2019 are knowledge ( $\rho$ value $=0.011$ and $O R=2.755$ ), economic status ( $\rho$ value $=0,007$ and $O R=2,909)$, condom use $(\rho$ value $=$ 0,001 and $O R=3,732$ ), support of health workers ( $\rho$ value $=$ 0,004 and $O R=3,201$ ), while those who are not related are sexual habits ( $\rho$ value $=0,267$ ).
\end{abstract}

\section{Keywords-HIV, Female Sex Workers, Cibitung}

\section{INTRODUCTION}

The problem of HIV and AIDS is a health challenge in almost all over the world, including in Indonesia. Since it was first discovered until December 2017 the number of people infected with HIV has been reported as many as 14,640 people. The highest percentage of HIV infections was reported in the age group of 25-49 years (69.6\%), followed by the age group 20-24 years $(17.6 \%)$, and the age group $\geq 50$ years $(6.7 \%)$, the ratio of HIV between male and female is $2: 1$. The highest percentage of HIV risk factors are risky sex among MSM (Male Sex) (28\%), heterosexuals (25\%), use of unsterile needles in IDUs $(2 \%)$, and others $(9 \%)$, whereas since first discovered until December 2017 the number of AIDS was reported as many as 4,725 people. The highest percentage of AIDS was in the $30-39$ years age group $(35.2 \%)$, followed by the 20-29 years age group (29.5\%) and the 40-49 years age group $(17.7 \%)$. The AIDS ratio between men and women is $2: 1$. The highest percentage of risk factors are risky sex in heterosexuals $(71 \%)$, homosexuals (male sex) $\left(20^{\circ} \%\right)$, perinatal (3\%) and IDU (2\%) [1]

The West Java Health Office noted 35,825 HIV cases had occurred in West Java from 1989 to September 2018. A total of 9,217 were declared AIDS spread in 27 cities and districts in West Java. Most of them occur in the city of Bandung. The scope of research I took was included in the area of Bekasi Regency with a case ratio of 1.363 people with HIV / AIDS. $13.7 \%$ to 1,551 cases with more men than women, consisting of 884 men and 667 women who support HIV / AIDS. Until now there are 13 Puskesmas that can undergo HIV / AIDS testing in Bekasi district, from the 13 puskesmas the highest data obtained in WanasariPuskesmas is 1522 sexy female workers (WPS) who are tested for HIV / AIDS, provided 54 (3), $55 \%$ ) female sex workers (WPS) who tested positive for using the HIV / AIDS virus. Analysis of HIV / AIDS incidence in female sex workers (WPS) in Wanasari Village, Cibitung District, Bekasi Regency [2]

There are several health problems in the world which until now have not been resolved. One of the health problems that is now a Global Issues is HIV and AIDS. HIV (Human Immunodeficiency Virus) is a virus that attacks the human immune system so that a person is easily absorbed by disease. People infected with HIV, sooner or later (2 to 10 years) will suffer from AIDS (Acquired Immuno Deficiency Syndrome) if not treated regularly. While AIDS is a collection of symptoms of the disease with the characteristics of severe immune deficiency and is a manifestation of end-stage HIV infection[3]

HIV was first reported to occur in 1981 in the United States. At first it seemed like a disease that was only 
transmitted by homosexual men. The longer the spread of this virus is increasingly widespread, especially to other community groups such as drug users through drugs and Haitian immigrants. If someone is positive for contracting HIV and AIDS is a big problem because until now AIDS has no cure and there is no vaccine that can prevent it. HIV virus attack This is supported by Sarafino who revealed that now there is no cure for AIDS (Osborn \& Young in Sarafino, 1994). Although the international community has responded to the HIV and AIDS pandemic, the spread of HIV continues to increase and cause more than 12,800 new infections every day. AIDS is now the leading cause of death in Africa and in a quarter of the world[4].

Since it was first discovered in 1987 until December 2017, HIV-AIDS has been reported by 421 (81.9\%) of 514 districts / cities in all provinces in Indonesia. The province that was first discovered by HIV-AIDS was the Province of Bali, while the last reported was the Province of West Sulawesi in 2012. The number of reported HIV cases from 2005 to 2017 has increased each. the year. The cumulative number of HIV infections reported up to December 2017 is 200,623 . The highest number of HIV infections were in DKI Jakarta $(51,981)$, followed by East Java $(39,633)$, Papua $(29,083)$, West Java $(28,964)$ and Central Java (22,292). The number of AIDS. Reported from the year. 2005 to 2017 is relatively stable every year. The cumulative number of AIDS from 1987 to December 2017 was 102,667 people. The highest number of AIDS according to occupation / status were housewives $(14,721)$, non-professional staff / employees $(14,116)$, followed by entrepreneurs / self-employed $(13,610)$, farmers / ranchers / fishermen (5,115), and unskilled laborers (4,583). The highest number of AIDS reported from Papua. (19,729), East Java (18,243), DKI Jakarta $(9,215)$, Central Java $(8,170)$, Bali $(7,441)$, and West Java $(6,502)$. The AIDS death rate (CFR) increased slightly from $1.07 \%$ in 2015 to $1.08 \%$ in December 2017.

\section{RESEARCH METHOD}

This type of research is analytic observation research, with case control design. Case control is a study conducted by comparing between two groups, namely the case group and the control group. Case control studies are carried out by identifying case groups and control groups, then retrospectively examining risk factors that might explain whether cases and controls can be exposed or not.

A. Research Object

Female Sexual Workers (WPS) in Wanasari Village, Cibitung District.

\section{B. Research Benefit}

Find out the great risk of cases of HIV / AIDS in Women Sexual Workers (WPS) in Wanasari Village, Cibitung District.

\section{RESULTS AND DISCUSSION}

\section{A. Results}

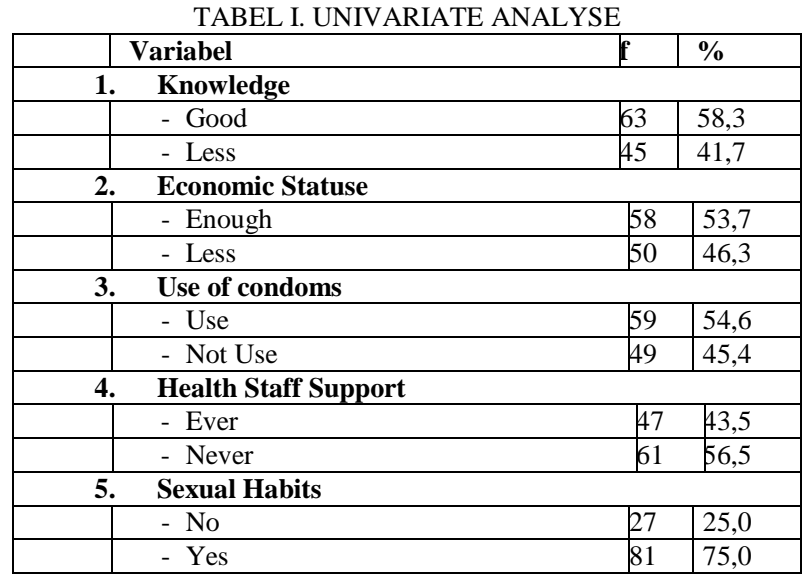

Of the 108 respondents classified as Female Sexual Workers whose knowledge is good as many as 63 peoples $(58.3 \%)$, Female Sexual Workers whose economic status is quite 58 peoples $(53.7 \%)$, Female Sexual Workers who use condoms use as many as 59 peoples $(54,6 \%), 61$ womens $(56.5 \%)$ who had the support of health workers $(56.5 \%)$, women who had sexual habits changed partners more than three times in one day as many as 81 peoples $(75 \%)$.

TABEL II. BIVARIATE ANALYSE

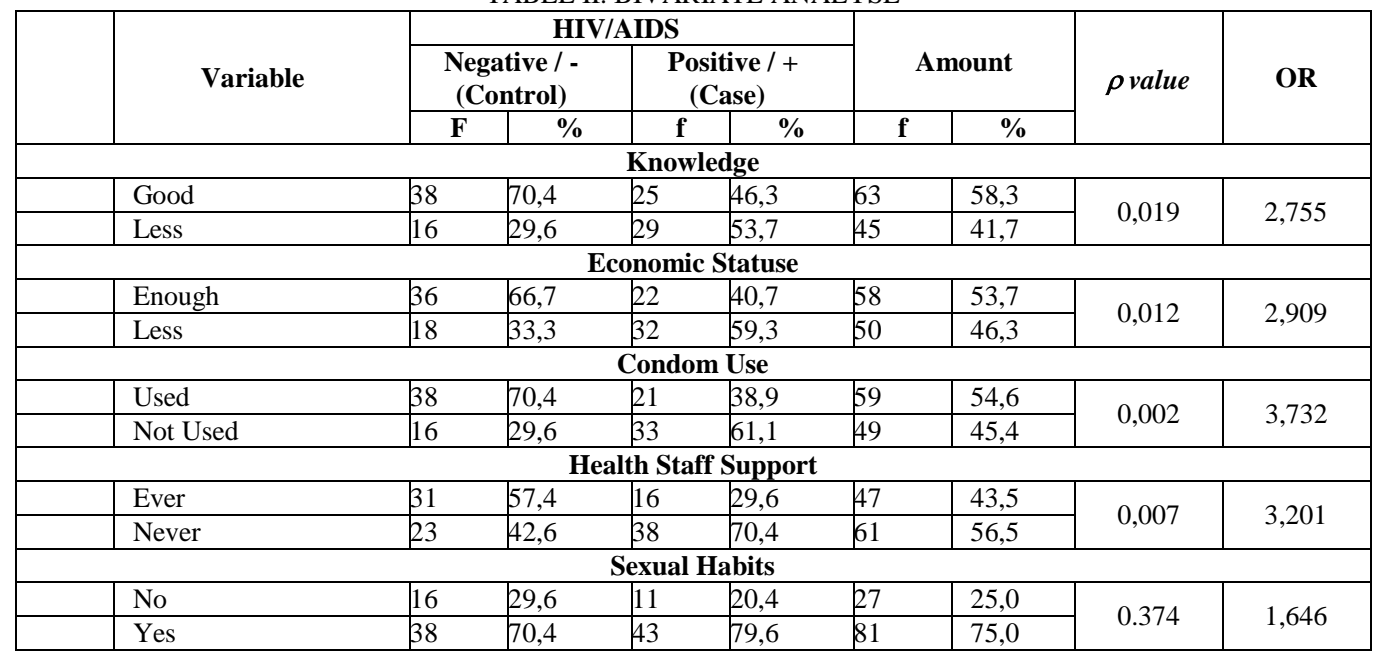


Less knowledgeable female sex workers who have HIV / AIDS positive 53.7\% with risk factors 2.7 times, less economic status who have HIV / AIDS positive $59.3 \%$ with risk factors 2.9 times, do not use condoms with HIV / AIDS positive $61.1 \%$ with risk factors 3.8 times, with no support of health workers who have HIV / AIDS $70.4 \%$ positive with risk factors 3.2 times, who have sexual habits who experience HIV / AIDS positive $79,6 \%$ with a risk factor of 1.7 times.

B. Discussions

The incidence of HIV / AIDS is very closely related to knowledge, because knowledge that is not good or lacking causes respondents to behave less towards the prevention of HIV / AIDS as a result can cause contracting this disease[5]. The problem that often occurs in families is an economic problem. Where is the inability to meet the needs in the family, so this condition forces parents from poor families to employ their children as sex workers.Lack of support from health workers can cause a lack of health information to be conveyed to the community including HIV / AIDS prevention issues. As a result it can increase unhealthy behavior in sexual behavior in the community so that it has an impact on increasing cases of HIV / AIDS[6].

Cognitive Consistency Theory states that knowledge is very important for the formation of a person's actions or behavior[7]. If someone knows about the transmission of HIV / AIDS through sexual contact, and so on, what are the dangers, that person will take action to prevent it.The use of condoms has been proven to reduce the spread of HIV / AIDS.[8] The use of condoms is an effective way to prevent transmission of HIV / AIDS.19 Sexual relations between FSWs and their customers without using condoms are high-risk behaviors for HIV transmission[9]. The more partners you have, the more likely one of them has been infected with HIV and is not aware of it. To reduce the number of HIV infections, the CDC recommends that each person only have sexual relations with one partner. Precautions can also be taken when you have sex, by using a condom and sexual activity that has a lower risk of transmission than anal or vaginal $\operatorname{sex}[10]$.

The occurrence of HIV / AIDS is very closely related to knowledge, because poor or inadequate knowledge results in respondents behaving less towards the prevention of HIV / AIDS which can consequently cause contracting this disease. The incidence of HIV / AIDS can also be caused by low economic factors, causing respondents to find any job to earn a living so they want to plunge into the dark world to become sex worker women who are vulnerable to HIV / AIDS. Income in a family is often related to how the family's ability in terms of meeting the needs of daily life for female sex workers, therefore female sex workers who have more than enough income will automatically affect the needs of daily life and are comfortable with work. as a sex worker [11]. the incidence of HIV / AIDS is closely related to the behavior of one of them by not using condoms during sexual intercourse. For women sex workers having sex is considered normal and also does not use condoms as a result susceptible to HIV / AIDS[12].

The use of condoms with the incidence of HIV / AIDS is very related but in the localization of Wanasari Village where the authors conducted the study there were still some female sex workers who had intercourse without using condoms on the grounds that the offered tariff was higher in comparison not to use condoms[13]. Health workers strongly influence female sex workers by providing motivation to use condoms to avoid HIV / AIDS [9]. Besides that health workers also provide free condoms to the localization site. The absence of sexual habits related to the incidence of HIV / AIDS can be caused by respondents who change partners more than three times a day will not get HIV / AIDS if they take good precautions such as using condoms and always checking themselves with health workers can reduce the risk of contracting HIV / AIDS[14]. Precautions can also be taken when you have sex, which is by using a condom and sexual activity that has a lower risk of transmission than anal or vaginal sex [10]

\section{RESULT AND SUGGESTION}

The results of a bivariate analysis study using the chi square test found that there was a relationship between knowledge, economic status, condom use and support of health workers with the incidence of HIV / AIDS in female sex workers in Wanasari Village, Cibitung District, Bekasi Regency in 2019. While sexual habits did not have a relationship significance. With the highest risk factor, condom use.

Puskesmas in the field of health promotion and NGOs engaged in the field of HIV / AIDS. In order to increase the knowledge of Women Workers to increase knowledge about HIV / AIDS both directly and indirectly and continuously by using communicative media that is in accordance with the ability to understand sexy women workers and is also associated with routine communication activities. For sexy female workers to always be able to add insight about health published about HIV / AIDS that sexy female workers can learn from health books, health magazines, and the internet.

\section{CONCLUSION}

Based on the results of the research, the conclusion is that there is a relationship between knowledge, economic status, condom use and support from health workers with the incidence of HIV / AIDS in female sex workers in Wanasari Village, Cibitung District, Bekasi Regency in 2019. Meanwhile, habitual sex does not have a significant relationship. With the highest risk factor, use of condoms.

\section{ACKNOWLEDGMENT}

Gratitude is expressed to the Universitas Nasional who has given who have supported and provided opportunities for the authors to conduct this research, gratitude is also expressed to Faculty of Health who always encourages to always work, also for families, friends who have been supporting both morally and materially. 


\section{REFERENCES}

[1] J. Sathian, B., \&Sreedharan, "Socio-Demographic Characteristics of Clients of Female Sex Workers and their Perspectives, Behaviors and Attitude on HIV and AIDS in Pokhara Valley: A Necessary Enquiry.," 2012.

[2] I. Wibowo, S. W. R., \&Jayatmi, "Perilaku Pemanfaatan Layanan Voluntary Counseling And Testing (VCT) pada Ibu Hamil," J. IlmiahK ebidanan Indones., vol. 8, no. 3, pp. 157$168,2018$.

[3] I. Maharani, I. S., \& Yudianti, "Praktik Pemberian Asi Dan Waktu Pelepasan Tali Pusat Bayi Baru Lahir.," J. Ilm. Kebidanan (Scientific J. Midwifery), Vol. 4, No. 2, Pp. 125-134, 2018.

[4] E. Eton, Treatment as Prevention: Updates on Efforts to Combat the HIV/AIDS Pandemic. .

[5] E. Yulianingsih, "Faktor-Faktor yang Berhubungan dengan Tindakan Berisiko Tertular HIV/AIDS pada Siswa SMA Negeri Di Kota Gorontalo," JKMU, vol. 5, no. 4, 2015.

[6] R. Anurmalasari, "Hubungan Antara PemahamanTentangHiv/Aids Dengan Kecemasan Tertular Hiv/Aids Pada Wps (Wanita Penjaja Seks) Langsung Di Cilacap," 2009.

[7] S. Notoatmodjo, Health Promotion \& Behavioral Sciences
(Promosi Kesehatan \& Ilmu Perilaku). Jakarta: RinekaCipta., 2015.

[8] A. Imron, Pendidikan kesehatan reproduksi remaja. Ar-ruzz Media., 2012.

[9] E. Kusmiran, "Gambaran Pengetahuan Remaja Tentang HIV/AIDS DI SMA N 85 Jakarta.," 2014.

[10] O. Cahyaningsih, "Hubungan Pengetahuan Dan Penggunaan Kondom PadaLaki-Laki Beresiko Tinggi (Operator Karaoke) Dalam Berhubungan Seksual Di Resosialisasi Argorejo Dan Rowosari Semarang.," J. Ilmu danT eknologi Kesehat., vol. 52, 2018.

[11] C. R. Tulung, O., Sondakh, R. C., \&Tilaar, "Hubungan antara Pengetahuan dan Sikap dengan Tindakan Pencegahan HIV/AIDS pada Siswa SMK Negeri 1 Tomohon.," Univ. Sam Ratulangi.

[12] Lubis, "Penggunaan Kondom.," Departemen Ilmu Kesehatan Kulit dan Kelamin Fakultas Kedokteran USU., 2008.

[13] L. L. Adolf, “Analisis jurnal Dukungan Keluarga, Dukungan Petugas Kesehatan, dan Perilaku Ibu HIV Dalam Pencegahan Penularan HIV atau AIDS ke Bayi.," 2019.

[14] D. M. Nuzzilah, N. A., \&Sukendra, "Analisis Pengetahuan dan Sikap Narapidana Kasus Narkoba Terhadap Perilaku Berisiko Penularan HIV/AIDS," J. Heal. Educ., vol. 2, no. 1, pp. 11-19, 2017. 